\title{
AN INTRODUCTION TO FIQH ZAKAT: \\ Definition, Normative Basis, and Social Implication
}

\author{
Anita Zonmi Putri, Aldo Yoga Pratama \\ UIN Imam Bojol Padang \\ e-mail: Aicaciaputri@gmail.com., aldoyogapratama07@gmail.com
}

\begin{abstract}
This paper aims to find out the ins and outs of Zakat related to the Meaning, Law, and its implementation. Its growth. Zakat is useful for setting aside life and property as well as the prosperity of the community. The status of Zakat is evident in the Qur'an and the hadith of the Prophet. With a descriptive analysis approach and a qualitative approach, the authors get the benefits of Zakat in Indonesia, not to mention the maximum, which is excellent potential in suppressing social inequality in society and increasing the productive economy. Zakat is focused on the poor and middle-class people. Zakat also supports the unity and integrity of Muslims in one solid integrity. It is appropriate that Zakat is protected by a clear legal umbrella to run more optimally and effectively as an instrument to reduce poverty and social inequality.
\end{abstract}

Keywords: Zakat, Definition, Goals and Social Implications

\section{INTRODUCTION}

Zakat is one of the third pillars of Islam; Zakat is the essential act of worship often in the Qur'an; Allah explainsZakat together by explaining prayer. In the eighty-two places where Allah mentions Zakat in conjunction with the matter of worship shows that Zakat and prayer have a very close relationship in terms of its priority; prayer is considered as the main body worship zakat is considered as the main worship Maliyah. Zakat is one of the pillars of Islam and is one of the main elements for the upholding of
Islamic Law. Therefore, the Law of Zakat is obligatory (obligatory) on every Muslim who has met certain conditions. Zakat is included in the category of worship (such as prayer, pilgrimage, and fasting), which has been arranged in detail and patent based on the Qur'an and the Sunnah as well as a social and humanitarian charity that can develop by the development of humanity. By conducting a literature study, the author took the step of a descriptive analysis approach and got the Meaning of Zakat literally and understanding 
the term. Then it was found that all Salaf and Khalaf scholars established that denying the Law of Zakat is denying the obligatory cause in the Law of disbelief. Therefore, we must know the definition of Zakat, the property that must be Zakat, the zakat nishabs, the procedure for the implementation of Zakat, and various kinds of Zakat (al-Zuhayli and AlKattani 2010, 88).

One aspect of Islamic teachings that have not been taken seriously is poverty alleviation by optimizing the collection and utilization of Zakat, infaq, and sadaqah in the broadest possible sense. This exemplified by Rasulullah SAW and his successors in the golden age of Islam. Muslims (Indonesia) have considerable potential for funds. Encouraged by this thought, the author tries to compile a brief and practical zakat paper so that قحف، ( محمد منذر, Islamic Development Bank, and Islamic Research and Training Institute 2001, 21). However, the authors are aware that this paper is far from perfect. However, the authors hope this treatise can be useful. The authors hope that criticism and suggestions are for the perfection of this zakat paper. The novelty of this discussion is the Meaning of Zakat by language and terminology and its application amid a society in overcoming social disparities and the importance of having a legal umbrella for thisZakat. The traditional umbrella is used as a catalyst in the implementation of Zakat to make it more effective as an agent for the development of social welfare for Indonesians, most of whom are Muslim(Akmal-ad-Dīn al-Bābartī, Marḡinānī, and Ibn-Maḥrūs 2007, 77).

\section{METHODS}

I've done this writing; a literature study was conducted to collect data in the form of classic books related to Zakat. These books explain the legal basis for Zakat and the use of Zakat that has been done from time to time. These books are șlāh Al-Nafs Bayna alRāzī Fī al-Ṭibb al-Rūhānī, Wa-alKirmān̄i F̄̄ al-Aqwāl al-Dhahabīyah written by Akmal-ad-Dīn al-Bābartī. This book explains the wisdom of Zakat and cleansing of soul and property. Meanwhile, the author's contemporary book also refers to Fiqh ala Mazahib al-Arba'a, which discusses in detail the development of Zakat in the modern era. With a descriptive analysis approach, the writer explains the function of Zakat and its implementation in Indonesia, which is adjusted to the times.

\section{DISCUSSION}

\section{Understanding of Zakat}

Zakat, viewed in terms of language, has many meanings, namely Al barakatu, which has the Meaning of 
blessing, Ath tharatu, which has purity, Al nama, which has the Meaning of growth and development, and ash shalahu, which has the Meaning of effectiveness. According to some experts, Zakat according to the language is as follows (Zuhailī 2002, 75/3):

a) According to Ibn Manzur in his book Lisanul' ArabZakat means النماء و الطهارة و البركة and blessed."

b) In Mu' jam Al-Wasith, it is explained that Zakat is the basic word (Masdar) which means: النماء والبر كة والطهارة و والصلاح Meaning:" Grow, bless, clean and reasonable. "

c) According to Abu Luwis al-Ma'lufi: Zakat is to grow, kindness, alms, purity and increase

d) According to Abdurrahman alالز كاة لغة هي تطهير و النماء Meaning: "Zakat according to language is to purify and grow."

e) According to Yusuf Qardhawi: الز كاة هeaning: "Zakat is a blessing, growing, clean and good."

In terminology, the Meaning of Zakat is presented by jurists. As the scholars within the Syafi'i school

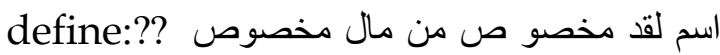
? يجب صر فه لأصناف مخصو صة صن بشرط Meaning: has been determined".

WhileZakat in terms of jurisprudence means "A certain amount of property that God obligates to be given to those who are entitled," in addition to means "issue a certain amount itself". The amount expended from the wealth is called Zakat because the expenditure adds a lot, making it more meaningful and protecting the wealth from destruction. So what is meant byZakat is to purify, grow because the property given by a person can cleanse his property from others and purify his property and, at the same time, can help others(Akmal-adDīn al-Bābartī, Margīnānī, and IbnMahrūs 2007, 70).

The Law of Issuing Zakat

Zakat is the fourth pillar of the five pillars of Islam and Zakat is also one of the Islamic banners whose enforcement should not be ignored by anyone. Zakat was made compulsory in Madinah in the month of Syawal in the second year of the migration after Muslims were required to fast during Ramadan. The basics or foundation of the obligation to pay Zakat are mentioned in(al-Zuhayli and AlKattani 2010, 78):

Al Qur'an: surat Al Baqarah; 43

"And establish prayer, pay zakat, and bow 'be with those who bow.'

a) Surah At Taubah; 103

"TakeZakat from some of their property, with that Zakat you clean and purify them and pray for them. Lo! Your prayer is for peace of mind.

An Introduction to Figh Zakat ... | 157 
and Allah is All-Hearing, AllKnowing."

b) Surah Al An'am; 141

"And he is the one who makes the gardens that are uplifted and those that are not encouraged, palm trees, crops with various fruits, olives and pomegranates that are similar (shape and colour) and not the same (taste). Eat of its fruit when it bears fruit, fulfil its right on the day of reaping the fruits of the harvest, and do not exaggerate. Indeed, Allah does not like those who are extravagant."

c) Surah At Taubah; 5

"When the Haram months are over, then kill the polytheists wherever you meet them, and arrest them. Surround them and wait for the reconnaissance place. If they repent and establish prayer and pay Zakat, then give them the freedom to walk [. Lo! Allah is Oft-Forgiving, Most Merciful.

As-Sunnah

a) Hadith narrated by Bukhari and Muslim from Abdullah bin Umar Rasulullah said

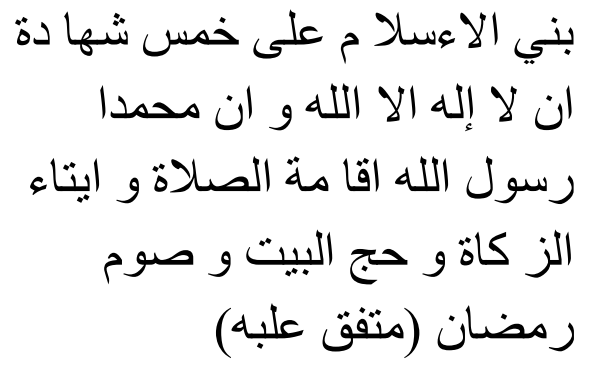

"Islam is upheld on five pillars: creed that affirms that there is no god but Allah and Muhammad is the messenger of Allah, establishing prayers, paying zakat, performing Hajj and fasting in the month of Ramadan" (H.R. Bukhari Muslim)

b) Hadith narrated by Ahmad and Muslim from Abu Hurairah

What can I do for you, but I do not know what to do with my life, I do not know what to do, I do not know what to do, I do not know what to do.

$$
\text { (رواه احمد و مسلم) (ر) (ر) }
$$

"A person who keeps his property without his Zakat will be burned in hell for him to be ironed from the fire, then ironed to his stomach and forehead-Al Hadits (HR Ahmad and Muslim)

c) Hadith narrated by Thabrani in the book Al Ausath and As Saghir from Ali

God forbid that I should be in the midst of them, but I do not know what they are, but I do not know what they are and what they are.

"Allah ta'ala obligates zakat on the property of the rich from the Muslims, a number that can relieve the poor among the poor will not suffer from hunger and clothing difficulties except because of the actions of the rich and the poor, remember Allah will judge them later firmly and torment them with pain." 
Ijma 'Ulama' (Ulama Consensus)

Scholars, both salaf (traditional) and

Khalaf (modern), have agreed on the obligation of Zakat, and for those who deny it means they have been infidels from Islam.

\section{Function of Zakat}

According to monzer kahf, the primary function of Zakat is to achieve socio-economic justice. Zakat is a simple transfer of a portion of a specific size for the rich (muzaki) to be allocated to the miskun (mustahik) (Sali, Saharuddin, and Rosdialena 2020). In the moral field, Zakat reduces greed and greed in the hearts of the rich. Meanwhile, in the social sector, zakat functions to eradicate poverty from society. In the economic field, Zakat prevents the accumulation of wealth among a small proportion of people and is a compulsory contribution of Muslims to the state treasury. On the other hand, Daud Ali stated that the functions and purposes of Zakat are(Sarahsī, Šāfi 'ī, and 'Inānī 2009, 77):

- Raise the degree of indigence.

- Help solve the problems of the gharimin, ibn sabil, and other mustahiks.

- Being stretching and fostering brotherhood among Muslims and humans in general.

- Eliminate the stingy and greedy nature of property owners.
- Eliminate envy and envy from the hearts of the poor.

- We are bridging the gap between the rich and the poor in society.

- Develop a sense of social responsibility in someone, especially those who have property.

- Educate humans to be disciplined in fulfilling their obligations and surrendering the rights of others to them, this means of equal distribution of income to achieve social justice.

\section{Zakat Position}

Zakat is a very significant act of worship and a very noble obligation. The position of Zakat in Islamic Law is tremendous by observing the following (al-Qaradawi et al. 1999, 53): First, Zakat is the fourth pillar of Islam. This has been explained by the hadith of Abdullah bin Umar radhiyallâhu' anhumâ,

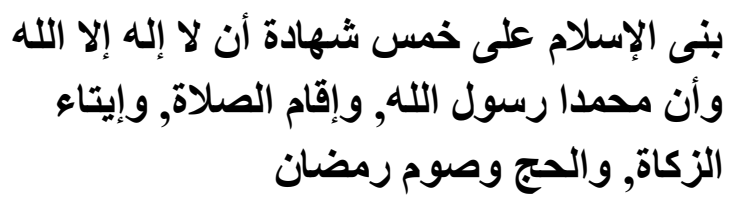

"Islam is built on five foundations; creed that there is no God but Allah and Muhammad Rasul Allah, upholding prayers, paying Zakat, hajj and fasting Ramadan. "

The mention of Zakat's obligation in the Qur'an is accompanied by the recognition of the prayer obligation in many verses.

An Introduction to Figh Zakat ... | 159 
Among them, Allah Subhânahu wa Ta'âlâ said,

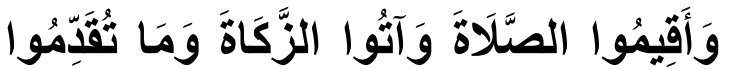

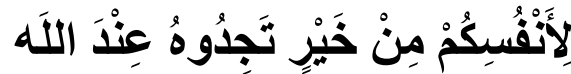

"And establish prayer and pay Zakat. And whatever good you do for yourselves, you will surely be rewarded by Allah. Lo! Allah is Seer of what ye do. " [Al-Baqarah: 110]

\section{ومم أُمِرُوا إلَّاّ لِيَعْبُدُوا اللَّهَ مُخْلِصِينَ لَهُ

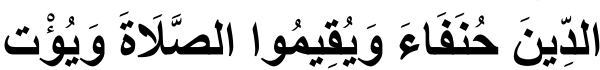

"Though they are not commanded, except to worship Allah by purifying obedience to Him in (performing) the right religion, and so that they establish prayer and pay Zakat; and such is the straight religion. "[AlBayyinah: 5]

Third, Zakat has been in the Law of those before us.

Allah Subhanahu wa Ta'âlâ said,

و إذ أخذنا ميثاق بني إسرائيل لا تعبدون إلا

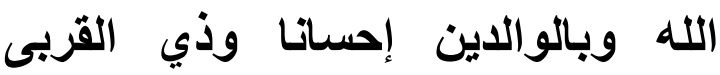
واليتامى والمساكين وقولوا للناس حسنا وأقيموا الصلاة وآتوا الزكاة ثم توليتم إلا قليلا منكم وأنتم معرضون.

"And (remember) when We took a promise from the Children of Israel, (that is) do not worship (anything), except Allah, do good to parents, relatives, orphans, and the poor, and say good words to people, establish prayer, and pay Zakat. Then you did not fulfil that promise, except a small part of you, and you always turned away. " [AlBaqarah: 83]
Regarding Prophet Ibrahim, Prophet Ishaq, and Prophet Ya'qub' alaihimus salâm, Allah Subhânahu wa Ta'âlâ explains,

\section{وجعلناهم أئمة يهدون بأمرنا وأوحينا إليهم فعل الخيرات وإقام الصلاة وإيتاء الزكاة وكاتوا لنا عابدين.}

"We have made them leaders who guide with Our command, and We have revealed to them (so that) they do good deeds, establish prayers, and pay zakat, and only to Us they always worship." [Al-Anbiyâ': 73]

Allah 'Azza wa Jalla mentions the words of Prophet Isa' alaihis salâm in the Al-Qur'an

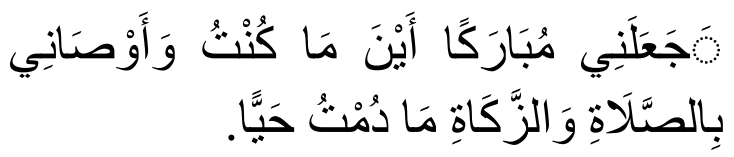

"And He made me a blessed person wherever I was, and He ordered me to (establish) prayer and (pay) zakat as long as I live." [Maryam: 31]Keempat, zakat adalah sifat khusus bagi orangorang yang beriman.

Allah Jalla Jalâluhu said,

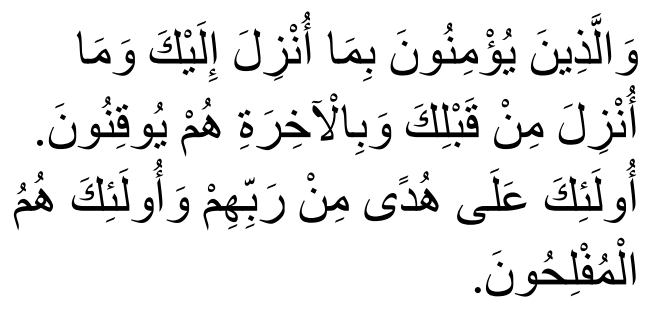

"And those who believe in the Book (Al-Qur'an) that has been sent down 
to you and (the books) that have been sent down before you, and they believe in the existence (life) of the hereafter. They are the ones who receive guidance from their Lord, and they are the lucky ones. " [AlBaqarah: 4-5]

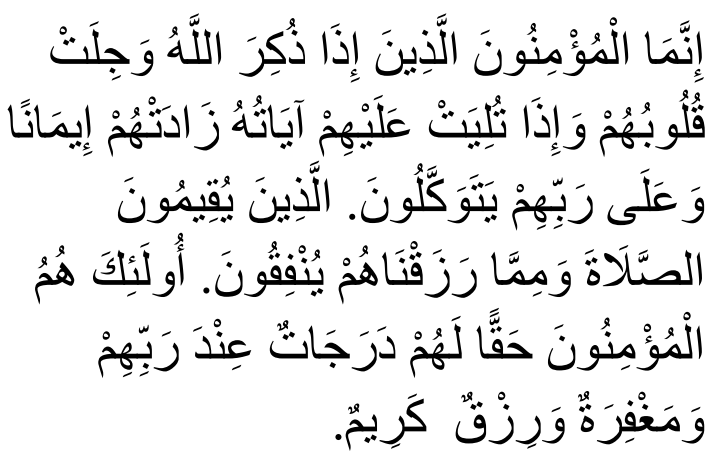

Those who believe are those who, when the name of Allah is mentioned, their hearts tremble and, when His verses are recited, their faith increases (therefore), and they trust only in their Lord. Those who establish prayer and spend out of what We have provided for them. Those are the ones who truly believe. They will obtain some degree of height in the sight of their Lord, as well as forgiveness and glorious sustenance (favours)." [Al-Anfâl: 2-4]

The verses which describe Zakat as a characteristic of believers are numerous to describe.

Fifth, Rasulullah shallallâhu' alaihi wa Sallam explained the details of zakat law in his hadiths with a very detailed explanation related to the types of property that areZakat, the rate of Zakat issued, places of distribution of
Zakat, and various other discussions. Insya Allah, there will be a mention of several hadiths on this matter, which show the greatness of the position of Zakat in Islamic Law. Sixth, Allah Subhânahu wa Ta'âlâ rebukes those who leaveZakat (Dakhoir 2019).

Allah Subhânahu wa Ta'âlâ said,

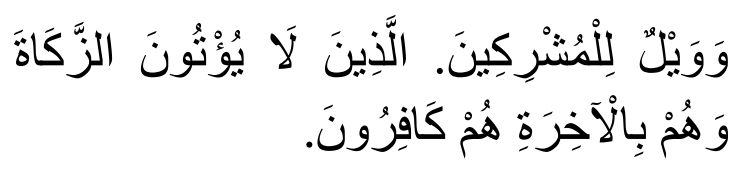

"And woe to the polytheists (those who associate with Him), (that is) those who do not pay zakat and they disbelieve in the (life) of the Hereafter." [Fushshilat: 6-7]

Seventh, those who do not feed to the polytheists who are guilty of sin. Allah Subhânahu wa Ta'âlâ asserts,

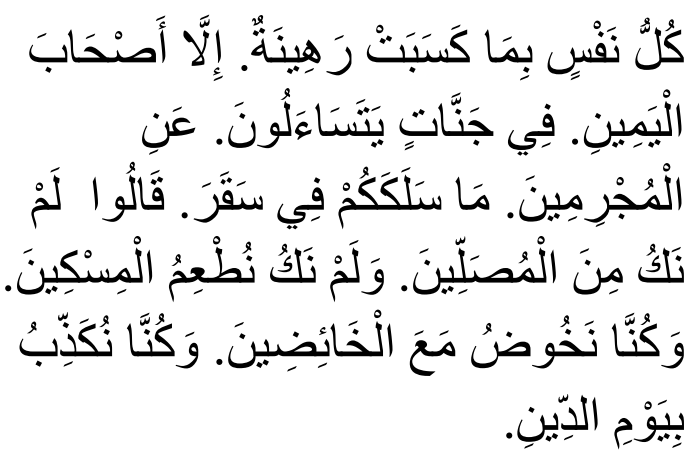

"Each self is responsible for what he has done, except for the right who is in heaven. They asked questions about (the condition of) sinners, 'What is the reason that put you in Saqar (hell)?' They replied, 'We were not among those who prayed, nor did we feed the poor. , and is we discuss things that are falsehood together with those who talk

An Introduction to Figh Zakat ... | | |6 
about them, and if we deny the day of vengeance. ' [Al-Muddatstsir: 38-46]

Eighth, purifyingZakat is something that causes a servant to be admitted to heaven and saved from the fire of hell. Allah Subhânahu wa Ta'âlâ said,

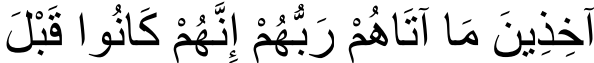

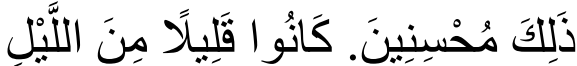

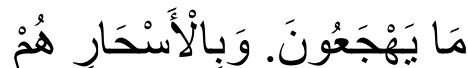

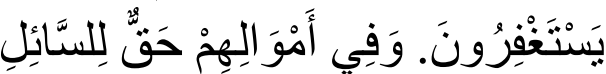
وَالْمَحْرُوِِ

"While receiving everything their Rabb gave them. Indeed, before that in the world, they were people who did good. In the world, they sleep very little at night. And always ask forgiveness in the morning before dawn. And on their property, there are rights for the poor who ask and the poor who do not receive a share. " [Adz-Dzâriyât: 16-19]

Allah Subhânahu wa Ta'âlâ also said,

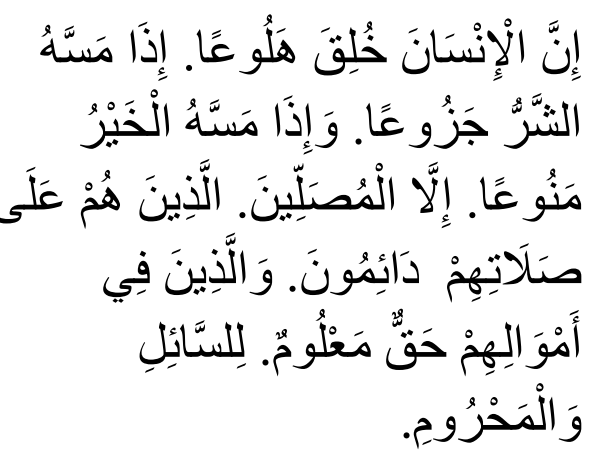

"Indeed, human beings were created to be complaining and misery. When an affliction befalls him, he complains. When he gets good, he is very stingy, except for those who perform the prayer, for whom they continue to serve the prayer and those in whose property there is a certain portion for the (poor) beggar and the who have nothing (who do not want to ask). " [Al-Ma'ârij: 1925]

For those who do not pay Zakat, even in the form of not feeding the poor, Allah Jalla Jalâluhu explains their situation on the Day of Judgment,

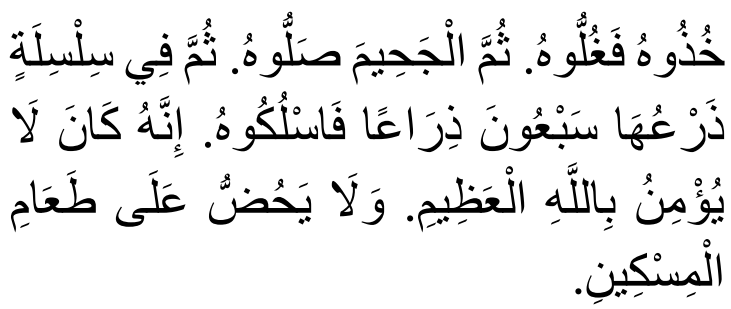

"Hold him and wrap his hand around his neck. Then put him in the blazing fire of hell. Then he twisted him with a chain that was seventy cubits long. Lo! He did not believe in Allah Almighty. Nor does he encourage (others) to feed the poor. " [Al-Haqqah: 30-34]

Ninth, those who do not pay Zakat can be fought by the government. The Prophet PBUH said,

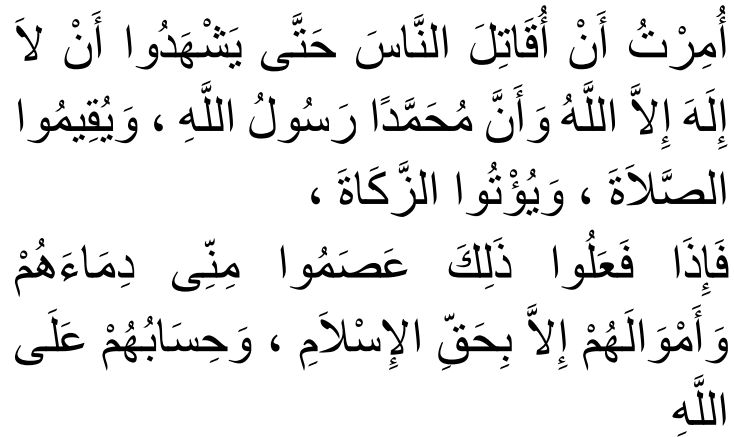

"I was ordered to fight people until they testified that no one has the right to be worshipped, except Allah, and that 
Muhammad is indeed the Messenger of Allah, upholding prayers, and issuingZakat. When they have done that, protect their blood and property, except with their Islamic rights and reckoning with Allah."

\section{Zakat Benefits}

\section{Religious Benefits}

Someone giving Zakat means having carried out one of the Pillars of Islam, which delivers a servant to happiness and safety in this world and the hereafter. Zakat is also a means for a servant to taqarrub (get closer) to his Rabb, will increase his faith due to his existence, which contains some kind of obedience. The payer of Zakat will get a double reward, as Allah says, which means: "Allah destroys usury and fertilizes alms" (Q.S.: Al Baqarah: 276). In a hadith that also explains that alms from the excellent property will be grown and developed by Allah many times over, Zakat is a means of remission of sins, as once said by the Prophet Muhammad SAW.

Khuluqiyah Benefits (Morals) ('Abd, Rāzī, and Kirmānī 1986, 91).

$\mathrm{He}$ is instilling the nature of glory, tolerance, and openness to the personal payer of Zakat. The payer of Zakat is usually identical with the spirit of mercy (compassion) and gentle to his relatives who do not have. It is a reality that donating something useful both in the form of property and body for the Muslims will open the chest and expand the soul because he will be a person who is loved and respected according to his level of sacrifice, and Zakat, there is the purification of

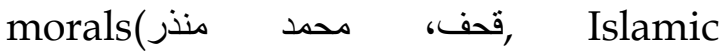
Development Bank, and Islamic Research and Training Institute 2001, 31).

\section{Ijtimaiyyah Benefits (Social Social)}

Zakat is a means to help in fulfilling the living needs of the poor, who are the majority group in most countries in the world. Provide strength support for Muslims and elevate their existence. This can be seen in the group of zakat recipients; one of them is mujahideen $f i$ sabilillah (Sali, Saharuddin, and Darni 2020). Zakat can reduce the social jealousy, resentment, and resentment that exists in the chest of the poor. Because the lower society usually if they see those of high economy class scattering property for something useless, it can ignite their hatred and enmity. If such abundant wealth is used to alleviate poverty, there will undoubtedly be harmony and love between the rich and the poor. That will drive the economic growth of the perpetrators, and obviously, its blessings will abound. PayingZakat means expanding the circulation of property or money because when the property is spent, its circulation will grow, and more parties will benefit(Abdul Latif Hidayah 2017, 14).

An Introduction to Figh Zakat ... | 163 
Theory of Zakat Management

Normative Theory and Perspective Along with the development of State and government, the State teaching of Law that is now adopted by the countries of the world is the Welfare State. The main feature of this State is the government's obligation to realize the general welfare of its citizens, about the organization of the State, to regulate the organization of the State and the order of government. So each State needs a constitution. The Constitution entirely regulates the relationship between the state institution and with the citizens of the State and declares itself the State of Law (Meirison 2020). Therefore, the participation of the people in the various functions of state life is one of the means to achieve law enforcement (Rule Of Law) or better known as the democratic system. In other words, the State of Law must be supported by a democratic system.

According to H.D. Van Wijk / Willem Konijnenbelt, they state the principles of Rechtstaat, or the rule of law, as follows (Mujaini Tarimin 2005, 91):

1. Government based on Law, the government, only has the powers expressly granted by the Constitution and other laws.

2. Human rights, there are fundamental human rights that must be respected by the government
3. Distribution of power, government authority may not be concentrated in an institution but must be divided into different organs to monitor each other and are intended to maintain balance.

4. Oversight of the judiciary, the exercise of government power must be proposed and assessed for its legal aspects by an independent judge. In the 19th century, Fredrich Julius Stahl's Rechtstaat concept emerged. According to Stahl, the elements of the Rule of Law (Rechtstaat) are as follows:

- Protection of human rights;

- Separation or distribution of powers to guarantee those rights;

- Separation based on statutory regulations;

- Administrative courts in Disputes. Simultaneously, the concept of the rule of Law (Rule Of Law) from A.V. Dicey was born under the Anglosaxon system. According to him, the elements of the Rule of Law are as follows, the supremacy of the Rule of Law (authority of Law), the absence of arbitrary power (absence of arbitrary power), in the sense that a person can only be punished if he violates the Law. Equality before the Law. This proposition applies to ordinary people and officials - the guarantee of human rights by Law (in other countries by the Constitution) and court decisions. 
Apart from that, according to B. Arif Sidharta, a rule of Law is a state which has the following basic elements and principles:

- First, recognition, respect, and protection of human personality (identity) implement the principles of distinction and protection of human dignity and freedom, which are the fundamental principles of the Rule of Law. Release here includes individual freedom, group freedom, ethnic community freedom, and national society freedom. Freedom and the possibility of factual implementation are not without limits but are determined and limited by welfare factors, accurate external conditions, philosophical and religious views, values, and determination of other principles and principles.

- Second, the principle of legal certainty that implements the following, citizens must be free from unpredictable and arbitrary actions by the government and its officials. In the sense that all government actions must rely on the rules outlined in positive Law.

- Third, the principle of equality (similia similibus). The government and its officials must treat everyone equally, and the laws apply equally to everyone.

- Fourth, the principle of democracy. This principle relates to the way of making decisions, in which every citizen has the same opportunity to influence the decisions and actions of the government.

- Fifth, the principle of government and its officials serving the function of the community. This principle describes a set of general principles for proper governance (algemeene beginselen van behoorlijk bestuur). The fundamental condition for human existence with human dignity must be guaranteed and formulated in statutory regulations.

In line with that, a fundamental concept of attention regarding the implementation of laws and regulations is the concept of authority, which plays an essential role in State Administrative Law. Authority in Dutch is called Bevoegheid, which is closely related to the management of the government in managing and implementing State power, as for the scope of authority not only includes decision-making by the police but also concerns the authority to carry out government tasks. Theoretically, management can be obtained in three ways (Uqaily 2010, 51):

1. Attribution: granting government authority by legislators to government organs;

Delegation: delegation of government authority from one

An Introduction to Figh Zakat ... | 165 
organ of government to another organ of government; Mandate: occurs when an organ of government allows the power to be exercised by another organ on its behalf. According to Bagir Manan (in Ridwan H.R) explains that rule in the language of the Law is not the same as power (Macht). Power only represents the right to do or not to act. In Law, the authority also means rights and obligations (Rechten en lichen). The concept of control, according to some scholars, is as follows: Philipus M. Hadjon: Government authority can be some free power or discretionary power, namely the authority to decide independently and the authority to interpret norms disguised but still subject to the Law. Herbert A. Simons: Authority is the power to make decisions and is related to superiors and subordinates. S.F. Marbun: authority is the ability to carry out a public legal action (juridical) and act given by Law to carry out legal relations. Prajudi Atmosudirjo: management is the power to carry out an available legal action(Dakhoir 2019).

\section{Theory of Legal Effectiveness (Sociological)}

It has been stated that the implementation and management of Zakat are not only played by the government; instead, it is aimed at members of the community, especially those who can have assets, are obliged to pay Zakat (Muzakki), and those who receive Zakat (Mustahik). In this regard, the Law is a means that aims to create harmony, integrity, order, and peace in social life. Or, in other words, the connection between order (external) and inner tranquility (al-Qaradawi et al. 1999, 37).

Thus the presence of Law is an integral part of people's lives, so it is difficult to imagine if a society can run in an orderly manner without the existence of laws governing it. The presence of the Zakat Management Law is essential for the development of the life of the people, especially for Mustahik, who is relatively very weak.

The second indicator, understanding the Law, means the amount of information a person has about the content of regulation. In other words, the understanding of the Law is an understanding or someone's mastery of specific laws, both regarding its substance and purpose.

The third indicator, legal attitude, means that someone tends to make individual judgments about the Law. A legal perspective will involve the choice of citizens towards the Law by the values that exist in them so that finally, the 
community accepts the Law based on respect for it.

Based on the psychological theory of attitude formation structures include:

The cognitive component (conceptual component) is related to knowledge, views on the object of attitude;

The affective component (emotional component) is related to feeling happy or unhappy with the object of the attitude;

The conative component (the behavioral component) is a component related to the attitude towards the attitude object.

The fourth indicator, the pattern of legal behavior, means that someone behaves by the applicable Law. On this subject, Friedman argues that: "Compliance is, in other words, knowing conformity with a norm or command, a deliberate instance of legal behavior that bends toward the legal act that provoked it ("Abd, Rāzì, and Kirmānī 1986, 99). Or the standard behavior in the middle, one crucial type, might be called evasion. Evasive action frustrates the goals of a legal act, but falls short of noncompliance or, as the case may be, legal culpability ". Based on this opinion, a person's behavior towards the Law can be classified in the form of obedience or Compliance, disobedience or deviance, and evasion or evasion.
Theoretically, a person's behavior is strongly influenced by internal factors, namely, psychological factors that exist in a person. This factor tends to move the person concerned to promote personal interests based on rational considerations so that this factor is what first moves a person to obey a provision because individuals always try to find convenience and benefit for themselves. Apart from internal factors, other factors that influence a person's behavior exist outside the person (external) in a social environment full of regulations and requirements (normative world). Internal factors can be referred to as the drivers and drivers of behavior, while external factors are the factors of formation or management.

In social life, these two factors are critical because they will determine the pattern of behavior that is manifested. The influence of these two factors will be seen from the citizens who are always moving and adjusting to the situations and conditions that will support their behavior. Furthermore, Giddens argues that three things influence the birth of behavior: First is reflective of action, second is ratio analysis of movement, and third is the motivation of action. Reflection monitoring of activity, the actions of individuals that are manifested 
based on the experiences of these individuals are created because of the relationship between one individual and another. Rationalization of action, which is an action taken by an individual based on logical/rational reasons because of the knowledge of the individual concerned. The motivation of action is a willingness of individuals based on the aspects of awareness and unconsciousness of individuals towards cognition and emotions ('Abd, Rāzī, and Kirmānī 1986, 77).

A person's behavior is often carried out consciously and unconsciously; action based on full awareness will benefit both himself and others. Therefore, the behavior should be supported by good intentions and with great attention. Fishbein, in this case, suggests that a person's choice to behave is influenced by his perception of the benefits of this behavior and his perception of the attitude of his peer group. Furthermore, Fishbein put forward several propositions, namely:

A person's behavior is influenced by his intention to act;

His beliefs influence a person's intention to perform certain behaviors about the consequences of these actions and their benefits for him;

His beliefs influence a person's intention to perform a particular behavior about the peer group's expectations and motivation to fulfill those expectations.

According to Hobbes and Freud, individual human behavior is egotistical and therefore tends to satisfy his interests. As a result of human nature, which tends to meet its interests, it often creates conflicts of interest with other parties, which, if not controlled, will result in social deviation (social deviation).

To analyze the operation of Law as a system, Friedman states that "A legal system in actual operation is a complex organism in which structure, substance, and culture interacts."

What is meant by structural components are the parts that move within a mechanism, such as legal organizations/institutions). The substantial piece is the actual results issued by the legal system (for example, traditional norms, including statutory regulations, decisions made by courts, or stipulated by government agencies). Meanwhile, the cultural component is the binding component of the system. It determines the place of the legal system in the middle of the culture/culture of the community (consisting of public values and attitudes) (Akmal-ad-Dīn al- 
Bābartī, Marḡīnānī, and IbnMahrūs 2007, 34).

Measurement of legal effectiveness or law enforcement can be seen through the norms in the Law itself, where what is meant by standards here, especially in this study, is the management of Zakat, according to Law Number 38 of 1999. In addition to the norms contained in the Law the Law itself. The effectiveness of the Law can be seen from the public's understanding of the models, which means that how is one's mastery of the material or content of laws and regulations.

Furthermore, it can be seen from the behavior of law enforcement officers, and it means that law enforcers are the spearhead of law enforcement in the field. When the substance of the Law is very responsive, the behavior of the people shows adherence to the norms. Still, if the apparatus cannot implement the standards, there will be imbalances in law enforcement.

Reviewing the operation of Law in society, according to Robert B. Seidman, there are 3 (three) elements related to it, namely:

1. Regulatory institutions;
2. Regulatory implementing agencies (bureaucracy);

3. Role holders.

Furthermore, Seidman stated that the behavior of the role holders could be determined by the legal regulations conveyed to him and by the overall social forces working in society. And the sanctioning institution/regulation will act following the applicable rules depending on the existing sanctions. Each role holder's behavior can constitute feedback that is conveyed to the regulator. However, the operation of the Law is not only determined by the statutory regulations, but also by other factors. Including the characteristics that determine the response to be given by the الاجتهاد الفقهي الدعاصر ( stakeholders are :هي السياسة الثرعبة 2010, 66 :

- sanctions contained therein;

- activities of law enforcement agencies/bodies;

- the entire complex of social, political, and other forces that work on the role holder. ${ }^{1}$

\section{Zakat Practices in Indonesia}

People in Indonesia usually distribute regular Zakat through zakat

\footnotetext{
${ }^{1}$ https://www.gurupendidikan.co.id/pengertianzakat/
} 
committees at mosques or national and private zakat institutions appointed by the government. In the distribution of Zakat in Indonesia, it seems that it has been channeled well; the people who are entitled to receive it have received or can be said to be right on target (Mujaini Tarimin 2005, 21).

Examples of zakat institutions in Indonesia are such as;

Republika Dhuafa Wallet

- Zakat House

- Development of Achievement People - Infaq Portal

- Baitul Maal Hidayatullah

- Baitulmaal Muamalat

-Justice Post Cares for the People And others.

\section{Zakat Issues in Indonesia}

The issue of Zakat is something that is never finished being discussed; the discourse continues to follow Islamic civilization. In Indonesia, the problems that arise with Zakat now: First, the role of Zakat as one of the pillars of Islam that capable Muslims (muzakki) must fulfill is only a personal awareness. PayingZakat is individual virtue and is very Sufistic so that it is more concerned with the dimension of eternity. Zakat should be a collective awareness movement; let's say that we can launch a zakat awareness movement, as proclaimed by President Megawati on December 2, 2001, at the Istiqlal Mosque on the commemoration of Nuzulul Qur'an, so that Zakat becomes the backbone of the people's economy. Because, Zakat is not only an obligation that contains a theological value, but also a financial burden that includes a high social cost. This problem cannot be separated from the people's understanding (who are obliged to doZakat) on the Meaning of the substance of Zakat (Jazīrī 2012, 59). Zakat is only a religious (theological) obligation to clean the property from dirtiness. People understand that about Zakat, finally, Zakat is given regardless of the future benefits for those who are entitled to receive it (Mustahiq). However, Zakat plays an essential and significant role in distributing income and wealth and has a real effect on consumer behavior. With zakat distribution smoothly and wealth does not circle the elite (conglomerate). However, lately, the awareness among other upper-middleclass Muslims has been getting better. Apart from paying taxes, they also pay Zakat. Second, the increasing awareness of Muslims in paying Zakat is not accompanied by a comprehensive planned collection and distribution. How canZakat, which has a significant role in determining the economy of the people, be managed professionally-productively and adequately. Management that is not good and professional makesZakat unproductive in contributing to developing the economy of the people. We used to have a semi-governmental 
BAZIS (Badan Amil Zakat and Shodaqah), now we have the Amil Zakat Agency (BAZ) and the Amil Zakat Institute (LAZ), which are fostered by the government at the will of the people. It's just that, the institutional system for Zakat is not the same as for tax institutions that have been considered healthy; it seems that BAZIS / BAZ / LAZ still seems weak. It is not easy to set targets-coupled with the issue of trust that zakat organizers lack (Mujaini Tarimin 2005, 23).

There are three keywords that zakat management organizations must hold to become good organizational governance: Amanah, Professional, and Transparent. Third, our formal-legal supporters are less proactive in seeing the potential of Zakat, which is also an application of religious adherence to Muslims. As stated by the leadership of DSUQ Bandung, the potential for Zakat in a year financially in Indonesia can reach 2 trillion rupiahs. That number can only be calculated from the number of rich people (muzaki) detected. But in reality, the collection of Zakat is still below the standard ratio of the average number of Muslims who are subject to the obligation of Zakat (muzakki). As a country where the majority of the population is Muslim, the State should be proactive in responding to the needs of the ummah, where basic Islamic teachings such as Zakat have become the backbone of the people's economy by giving birth to the zakat law since independence (Sali, Saharuddin, and Darni 2020).

The birth of Law No. 38 of 1999 concerning the management of Zakat, which was passed on September 23, 1999, although it is never too late, it does not provide much fresh air to Muslims in realizing a robust economic order. However, we can still be grateful for the birth of this Law even though there was a tug of war between the interests of (the rulers and the people) in the delivery of the Law. It was coupled with the amendment to the Income Tax Law No. 17 of 2000, which was passed on August 2, 2000, where Zakat is a deduction for tax payments. Income. Both laws provide guarantees to Muslims that Zakat will be appropriately managed, although there is much concern that the Law is only a half-hearted movement that only encourages Muslims and will stop halfway.

This concern is evident from the stagnation in the efforts to socialize and realize the two laws. The occurrence of many obstacles in the socialization, realization, and technicality became a very dominant factor in the stagnation of the Law. Why did this happen? We may look with cynical eyes on the government in applying the concept of Zakat by saying that the existing zakat law is only a half-hearted gesture. Or we can 
see the various weaknesses that exist in Law No. 38/99 on Zakat Management and Law no. 7/83 Jo. Law No.10 / 94 Jo. U.U. no. 17/2000 on Income Tax as a deduction for tax payments when paying Zakat for Muslims. As stated by Hadi Muhammad in a paper on the weaknesses of the Law, said: "The Prepaid Tax method is better than the Deductible Expenses method used in Law No. 38/99. It is just an excuse from the tax directorate general's apparatus to show bureaucratic tolerance towards the provisions of tithing by Muslims (Wibisono 2015, 55). "

\section{CONCLUSION}

Zakat is one of the fourth pillars of Islam, whose Law is obligatory or obligatory on every person who has sufficient conditions. Zakat is divided into things that must be Zakat, Nisab, people or groups who are entitled to receive Zakat and do not receive. Hopefully, with us discussing this paper adds to our insight on Zakat. Zakat is one of the pillars of Islam whose implementation is based on sharia / Islamic law. Apart from being ritual worship, Zakat is also social worship and has a political dimension associated with state involvement in its management. The management of Zakat has led to a formal, collective, organized, and permanent structure since the time of the Prophet
Muhammad Sallallahu "Alayhi wa Sallam.

Along with the development of Islamic territory, the level of the economy, which is increasingly advanced, and the government structure is increasingly complex; zakat management policies change dynamically according to the evolving times. The forms of zakat management and state involvement in zakat management also vary. The power of Zakat in Indonesia has also developed in such away. As a country that has the largest Muslim population in the world, the issue of Zakat has become inseparable from the social life of the Indonesian people. The State of Indonesia is not a religious / Islamic state. The Islamic religious Law is used as the basis of the state constitution, but a democracy that makes religious values the basis of the Constitution. In countries where Islam is the basis of the state constitution, the implementation of Zakat is an obligation. There is coercion from the State on citizens to pay Zakat, and there are sanctions for negligence in paying Zakat. In these countries, Zakat is included in the state financial system; it can even be said to be a compulsory tax for Muslims because these countries do not impose tariffs on Muslims to accept Zakat. 


\section{REFERENCES}

Abdul Latif Hidayah, Abdullatif Hidayah. 2017. Nawazil Fiqhiyah Fi Al-Amal al-Qadha'i alMaghribi. Rabath: Maktabah Rabath.

Akmal-ad-Dīn al-Bābartī, Muhammad Ibn-Maḥmūd, Burhān-ad-Dīn 'Alī-Ibn-Abī-Bakr al-Margīinānī, and Abū-Mahrūs 'Amr IbnMaḥrūs. 2007. al- 'Ināya šarḥ alhidàya: wa-huwa šarh 'ala' 'lHidāya šarh bidāyat al-mubtadī fi furū 'al-figh al-ḥanafi li-Burhānad-Dìn 'Alì-Ibn-Abì-Bakr alMarğinānī. Bairūt: Dār al-Kutub al-'Ilmīya.

Dakhoir, Ahmad. 2019. “Al-Qardawi's Thought on Zakat of Stocks in a Modern Industry: An

Experience of Indonesia." AlManahij: Jurnal Kajian Hukum Islam 13 (2): 159-68.

https://doi.org/10.24090/mnh .v13i2.2023.

'Abd, 'Abd al-Lațîf Muhammad, Abū Bakr Muhammad ibn Zakarīyā Rāzì, and Ḥamīd al-Dīn Aḥmad ibn 'Abd Allāh Kirmānī. 1986. Ișlāh Al-Nafs Bayna al-Rāzì Fì alTỉbb al-Rūḥānī, Wa-al-Kirmānī Fì al-Aqwāl al-Dhahabiyah. AlȚab'ah 2. al-Qāhirah: Dār alThaqāfah al-'Arabìyah.
Jazīrī, 'Abd al-Raḥmān. 2012. Kitāb alfigh 'alá al-madhāhib al-arba 'ah. Bayrūt: Dār Ibn Ḥazm.

Meirison, Meirison. 2020. "The Impact of Foreign Capitulation on Islamic Sharia in The Ottoman Empire." Justicia Islamica 17 (1): 109. https://doi.org/10.21154/justi cia.v17i1.1554.

Mujaini Tarimin. 2005. Zakat: Menuju Pengurusan Profesional. Kuala Lumpur: Utusan Publications and Distributors.

Qaradawi, Yusuf al-, Monzer Kahf, Abdal-Haqq Bewley, and Mohmed Isa Waly. 1999. Fiqh Az-Zakat: A Comparative Study. London: Dar Al-Taqwa Ltd.

Sali, Meirison Alizar, Desmadi

Saharuddin, and Rosdialena Rosdialena. 2020. “Takhrij Fikih Dan Permasalahan Kontemporer." Al-Istinbath: Jurnal Hukum Islam 5 (1): 51. https://doi.org/10.29240/jhi.v 5i1.1235.

Sali, Meirison Alizar, Desmadi Saharuddin Saharuddin, and Darni Yusna Darni. 2020. "Ottoman Trade Policy and Activities in Europe and Asia." AL-FALAH : Journal of Islamic Economics 5 (1): 1. https://doi.org/10.29240/alfal ah.v5i1.1181. 
Sarahsīi, Muhammad Ibn-Aḥmad as-, Abū-'Abdallāh Muhammad Hasan Muhammad Hasan Ismā 'īl aš-Šāfi 'ī, and Kamāl 'Abd-al-' Aẓīm al-'Inānī. 2009. Kitāb al-Mabșūt fi 'l-fiqh alhanafi. Bairūt: Dār al-Kutub al'Ilmīya.

Uqaily, Ali Mahmud Uqaily. 2010. Praktis \& Mudah Menghitung Zakat. Solo: Aqwam.

Wibisono, Yusuf. 2015. Mengelola Zakat Indonesia: Diskursus Pengelolaan Zakat Nasional Dari Rezim Undang-Undang No. 38 Tahun 1999 Ke Rezim UndangUndang No. 23 Tahun 2011. Edisi pertama. Rawamangun, Jakarta, Indonesia: Kencana.

Zuhailī, Wahba az-. 2002. al-Figh alislāmì wa-adillatuhū: aš-šāmil li'l-adilla aš-šar 'ìya wa-'l-ārā almadhabiya wa-ahamm an- nazarìyāt al-fiqhīya wa-tahqīq alahàdìt an-nabawìya wa-tahrīğihā mulhaqan bih̀̄ fahrasa alfābā' 'ìya šāmila li- 'l-mauḍu' 'āt wa- 'lmasā'il al-fiqhìya. Ğuz' 11: alFahāris al- 'āmma: fahrasa alfabā' 'ỳia šāmila li- 'l-āyāt wa- 'lahādìt wa-'l-mauḍu' 'āt al-fiqhīya. Nachdr. der vierten verb. Ausg. Dimašq Bairūt: Dār al-fikr. Zuhayli, Wahbah al-, and Abdul Hayyie Al-Kattani. 2010. Fiqih Islam wa adillatuhu. Kuala Lumpur: Darul Fikir.

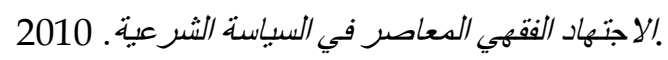

,قحف، محمد منذر Islamic Development Bank, and Islamic Research and

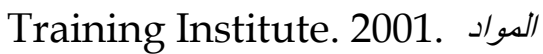
العلية لبرنامج التندبيب على تطبيق الزكاة في العي

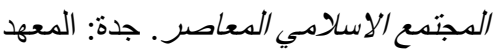
الاسلامي للبحوث و التنريب، البنك الاسلامي

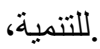

